\title{
PELATIHAN ALTRUISME DALAM KERELAWANAN PADA MAHASISWA KOMUNITAS PSIKOSOSIAL
}

\author{
Ugung Dwi Ario Wibowo \\ ugungs@yahoo.com
}

\section{UNIVERSITAS MUHAMMADIYAH PURWOKERTO}

\begin{abstract}
ABSTRAK
Kesiapsiagaan dan pencegahan adalah kunci utama penanggulangan bencana di Indonesia sebagai negara supermarket bencana. Agar bisa berkontribusi aktif, para relawan milenial yang tergabung dalam mahasiswa Komunitas Psikososial Fakultas Psikologi Universitas Muhammadiyah Purwokerto harus memiliki sikap altruisme selain memahami manajemen kebencanaan. Pengabdian masyarakat Pelatihan Altruisme dalam Kerelawanan pada Mahasiswa Relawan Komunitas Psikososial diikuti oleh 24 peserta. Metode pelaksanaan kegiatan ini yaitu: analisis kebutuhan pelatihan, pelaksanaan pelatihan, dan evaluasi kegiatan. Kegiatan dilakukan pada tanggal 2 April 2021 di PPIT Al Ittihad, Kecamatan Kemranjen, Kabupaten Banyumas. Materi yang diberikan: (1) mengenal konsep kerelawanan dan kebencanaan; (2) konsep dasar dan pemahaman altruisme yang terdiri dari empati, sikap sukarela, dan perilaku menolong; (3) pengembangan dasar altruisme dalam kerelawanan; dan (4) implementasi altruisme sesuai dengan aktivitas dan kapasitas relawan kebencanaan. Kesimpulannya, kegiatan pengabdian masyarakat pelatihan altruisme dalam kerelawanan sangat tepat diterapkan sebagai salah satu upaya membentuk relawan yang baru bergabung di komunitas psikososial untuk memiliki sikap altruisme. Metode ceramah interaktif, diskusi, dan simulasi menjadi metode yang tepat untuk memberi pemahaman dan implementasi sikap altruisme dalam kerelawanan. Tindak lanjut dari pelatihan alruisme dalam kerelawanan pada mahasiswa komunitas psikososial yaitu pendampingan pasca pelatihan.
\end{abstract}

Kata kunci: Ceramah Interaktif, Diskusi, Kerelawanan, Pelatihan Altruism, Simulasi.

\section{PENDAHULUAN}

Indonesia sering disebut sebagai negara "supermarket" bencana dengan beragam risiko bencana alam, seperti: tsunami, gempa bumi, gunung meletus, banjir, kekeringan hingga bencana yang bukan berasal dari alam seperti penyebaran virus penyakit. Indonesia memiliki 950 patahan yang mayoritas berada di daratan sehingga rentan akan terjadinya gempa. Indonesia memiliki 500 gunung api yang mana 127 diantaranya dalam keadaan aktif dan gunung merapi masuk kategori super aktif.
Kesiapsiagaan dan pencegahan adalah kunci utama penanggulangan bencana. 3.814 kejadian bencana tahun 2019 menyebabkan 418 jiwa meninggal sedangkan pada awal tahun 2020 (data per 1 - 15 Januari 2020) telah terjadi 166 kejadian bencana yang menyebabkan 71 jiwa meninggal. Hal ini menunjukkan bahwa pemahaman masyarakat akan kebencanaan perlu ditingkatkan untuk masyarakat agar tercipta kesadaran dan melahirkan budaya sadar bencana bahkan relawan bencana (www.bnpb.go.id). 
Kebencanaan yang terjadi di Indonesia membuat banyak lembaga terkait dengan bencana alam baik pemerintah maupun nonpemerintah. Salah satu lembaga penganggulangan bencana yang konsisten dengan kerelawanan bencana yaitu Muhammadiyah Disaster Management Center atau disingkat MDMC, yang memiliki banyak underbone (organisasi/komunitas turunan), salah satunya yaitu Mahasiswa Komunitas Psikososial.

Komunitas psikososial merupakan komunitas mahasiswa relawan dari Fakultas Psikologi Universitas Muhammadiyah Purwokerto yang memiliki komitmen untuk melakukan pertolongan psikososial terhadap penyintas bencana alam dan non-alam. Seluruh relawan yang diberangkatkan untuk respon (aksi turun lapangan) telah mengikuti pendidikan dan pelatihan sebagai syarat wajib sebagai relawan baik terkait penanganan psikososial maupun keterampilan terkait kebencanaan lainnya.

Beberapa kiprah mahasiswa komunitas psikosial yang berdiri sejak tahun 2018 dalam respon kebencanaan didokumentasikan sebagai berikut:

1. Respon bencana gempa bumi di Kecamatan Kalibening, Kabupaten Banjarnegara, bulan Maret sampai dengan Mei 2018 dengan memberangkatkan 20 relawan;

2. Respon bencana gempa bumi di Lombok, Nusa Tenggara Barat, tanggal 9 sampai dengan 22 Agustus 2018 dengan memberangkatkan 8 relawan;

3. Respon bencana gempa bumi, tsunami, dan likuifaksi di Palu, Sigi, dan Donggala, Sulawesi Tengah, tanggal 30 November sampai dengan 24 Desember 2018 dengan memberangkatkan 14 relawan;

4. Respon bencana tsunami di Kalianda, Bandar Lampung, tanggal 20 sampai dengan 30 Januari 2019 dengan memberangkatkan 8 relawan;

5. Respon bencana wabah covid-19 untuk masyarakat Jawa Tengah selama bulan Maret sampai dengan Juni 2020 dengan melibatkan minimal 15 relawan;

6. Respon banjir di Kemranjen, Kabupaten Banyumas, tanggal 30 Oktober sampai dengan 18 November 2020 dengan memberangkatkan 18 relawan;

7. Respon tanah bergerak di Tumanggal, Kabupaten Purbalingga tanggal 8 sampai dengan 20 Desember 2020 dengan memberangkatkan 14 relawan; dan

8. Respon gempa bumi di Lumajang, Jawa Timur tanggal 16 s.d 23 April 2021 dengan memberangkatkan 1 relawan bergabung BPBD Jawa Tengah.
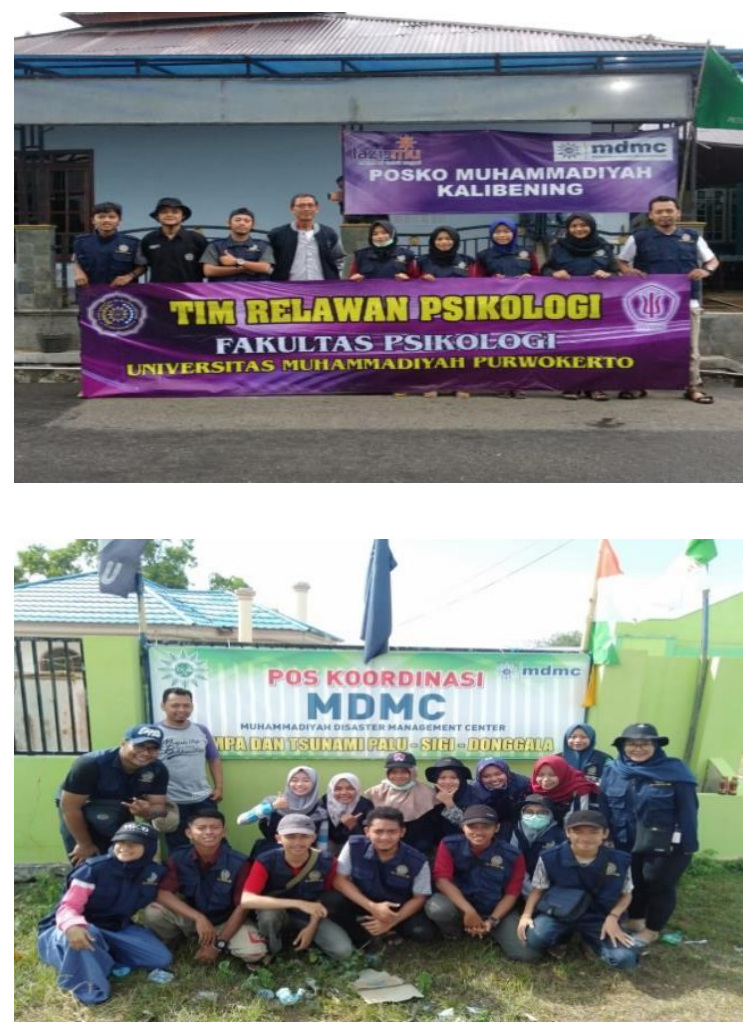

Gambar 1. Respon Gempa Bumi di Kalibening dan Gempa Bumi/Tsunami di Palu 


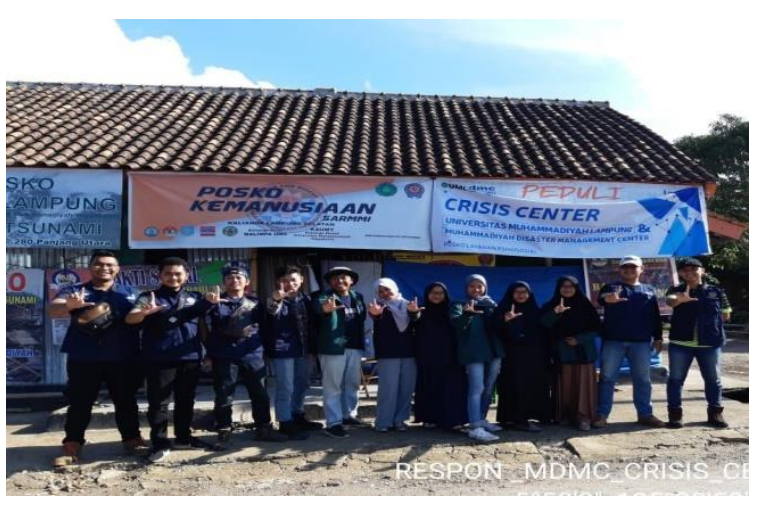

\#prayforlombok

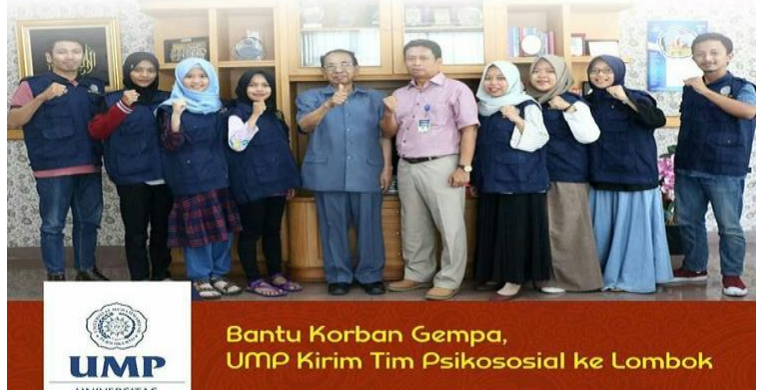

Gambar 2. Respon Tsunami Selat Sunda di Lampung dan Gempa Bumi di Lombok NTB

Relawan milenial yang tergabung dalam Mahasiswa Komunitas Psikososial telah mengerti tentang manajemen bencana yang di dalamnya berbicara tentang mitigasi, kesiapsiagaan, ketangguhan, kapasitas, kerentanan, penyusunan rencana penanggulangan bencana, rencana kontijensi, rencana operasional, jitupasna, pendampingan korban bencana, serta memahami klasterisasi dan sejenisnya (www.bnpb.go.id). Edukasi kepada relawan agar dapat bergiat di tiga fase penanggulangan bencana. di fase prabencana, saat bencana, dan pasca bencana.

Pada tahun 2021, generasi pertama dari relawan Mahasiswa Komunitas Psikososial mulai berkurang karena sebagian sudah lulus sarjana dan tidak aktif di komunitas psikososial. Kaderisasi telah dilakukan secara bertahap setiap tahun melalui kegiatan dan respon di lapangan. Untuk menumbuhkan sikap kerelawanan para mahasiswa perlu dimunculkan sikap altruisme pada diri relawan yang masih milenial, sebagai salah satu sikap dasar relawan bencana (Khairil, 2014). Apalagi menurut Karmakar dan Ghosh (2012), pada pemuda/remaja jiwa menolong atas ketidakadilan dan ketidakberdayaan biasa muncul dan menjadi semangat dalam aktivitas sosial mereka.

Altruisme sebagai suatu sikap atau naluri untuk memperhatikan dan mengutamakan kepentingan dan kebaikan orang lain. Baron \& Byrne (dalam Kamilah \& Erlyani, 2017) mendefinisikan altruisme sebagai tingkah laku yang memunculkan pertimbangan untuk tidak mementingkan diri sendiri demi kebaikan orang lain.

Myers (Permatahati, 2016) menyatakan bahwa altruisme memiliki beberapa aspek, yaitu: (1) empati sebagai kemampuan merasakan, memahami dan perduli terhadap perasaan yang dialami orang lain; (2) sukarela sebagai suatu perbuatan positif tanpa ada keinginan untuk mendapatkan imbalan; dan (3) keinginan memberikan bantuan kepada orang lain.

Sikap altruisme pada setiap relawan Mahasiswa Komunitas Psikososial akan menjadi daya dorong terciptanya organisasi yang produktif dan optimal (Kamilah dan Erlyani, 2017), yang juga disebut extra-role behavior. Dengan begitu, relawan mahasiswa yang tergabung dalam komunitas psikososial memiliki sikap altruism dan bisa memajukan diri agar selalu menunjukkan performa dan sikap kerja yang menunjang tujuan kerelawanan dan organisasi yang menaunginya (Moscovici, 2015).

Kegiatan pengabdian masyarakat ini bertujuan agar peserta pelatihan yaitu para Mahasiswa Komunitas Psikososial bisa memiliki sikap altruisme dan perilaku menolong yang efektif dalam konteks bekerjasama dalam tim maupun dalam kerelawanan saat penanganan bencana. Manfaat dari pengabdian masyarakat ini yaitu mempersiapkan kader mahasiswa komunitas psikososial agar siap menjadi relawan saat dibutuhkan dalam respon kebencanaan di Indonesia. 


\section{METODOLOGI PELAKSANAAN}

Metode pelaksanaan kegiatan pengabdian masyarakat Pelatihan Altruisme dalam Kerelawanan pada Mahasiswa Relawan Komunitas Psikososial dilaksanakan sebagai berikut:

1. Analisis Kebutuhan Pelatihan. Metode yang digunakan yaitu wawancara formal dengan ketua dan sampel anggota Mahasiswa Komunitas Psikososial. Diharapkan dari hasil analisis kebutuhan pelatihan kemudian bisa dibuat modul dan materi yang efektif dan aplikatif. Hasil wawancara menunjukkan bahwa sikap altruisme merupakan salah satu aspek personal yang perlu ditingkatkan dalam bekerja sebagai relawan, selain keterampilan teknis kebencanaan dan kecakapan administratif para relawan.

2. Tahapan Pelatihan Altruisme dalam Kerelawanan pada Mahasiswa Relawan Komunitas Psikososial yaitu dengan mengenalkan dan mempraktikkan berbagai hal untuk meningkatkan efektivitas organisasi menggunakan konsep Myers (Permatahati, 2016), di antaranya: (1) mengenal konsep kerelawanan; (2) konsep dasar dan pemahaman altruisme dengan aspek empati, sukarela, dan perilaku menolong; (3) pengembangan sikap altruisme dalam kerelawanan; serta (4) implementasi altruisme sesuai dengan aktivitas dan kapasitas dalam rangka menguatkan keterampilan sebagai relawan kebencanaan. Dalam Khairil (2014), Moscovici (2015, Permatahati (2016) dinyatakan bahwa pada pelatihan altruisme beberapa aspek yang harus dikembangkan, pertama yaitu empati sebagai kemampuan merasakan, memahami dan peduli terhadap perasaan yang dialami orang lain; kedua yaitu perilaku sukarela sebagai perbuatan membantu orang lain tanpa ada keinginan untuk mendapatkan imbalan; dan ketiga yaitu keinginan menolong dan memberikan bantuan kepada orang lain.

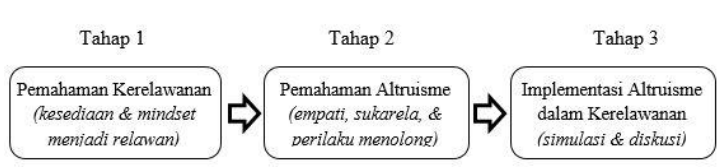

Gambar 3. Tahapan Pengembangan

Altruisme dalam Kerelawanan

3. Dalam pelaksanaan pelatihan, metode yang digunakan yaitu: (1) metode ceramah interaktif: proses penyampaian pengetahuan dan pemahaman terkait materi secara 2 (dua) arah di ruang kelas; (2) metode diskusi: proses pembelajaran interaktif secara berkelompok antara peserta untuk menemukenali sikap altruisme secara kognitif, afektif, dan psikomotorik, sampai dipahami secara bersama; dan (3) metode simulasi melalui games: melakukan experiential learning dengan games serta melakukan debrief di akhir sesi untuk merefleksikan apa yang dialami dalam mengimplementasikan.

4. Evaluasi Kegiatan Pasca Pelatihan. Metode yang digunakan yaitu evaluasi formatif (tentang proses pelatihan) dan evaluasi sumatif (evaluasi hasil pelatihan). Evaluasi dilakukan seketika pasca pelatihan dan dengan observasi jeda pasca pelatihan.

\section{HASIL DAN LUARAN}

Pelatihan Altruisme dalam Kerelawanan pada Mahasiswa Komunitas Psikososial dilaksanakan pada tanggal 2 April 2021 bertempat di Pondok Pesantren Islam Terpadu Al-Ittihad Kebarongan Kemranjen dan area Kemranjen yang sempat terdampak banjir di bulan November 2020. Pelaksanaan kegiatan pelatihan dilakukan dengan mengikuti protokol kesehatan, dengan persyaratan peserta wajib melampirkan surat keterangan sehat atau surat hasil tes rapid covid-19.

Khalayak sasaran Pelatihan Altruisme dalam Kerelawanan pada Mahasiswa Komunitas Psikososial ini yaitu para relawan Mahasiswa Komunitas Psikososial Fakultas Psikologi Universitas Muhammadiyah Purwokerto, yang 
sekaligus dirangkai dalam Diksar Psikososial sejumlah 24 (dua puluh empat) relawan mahasiswa yang berasal dari relawan mahasiswa Fakultas Psikologi Universitas Muhammadiyah Purwokerto semester 2 (dua) dan semester 4 (empat).
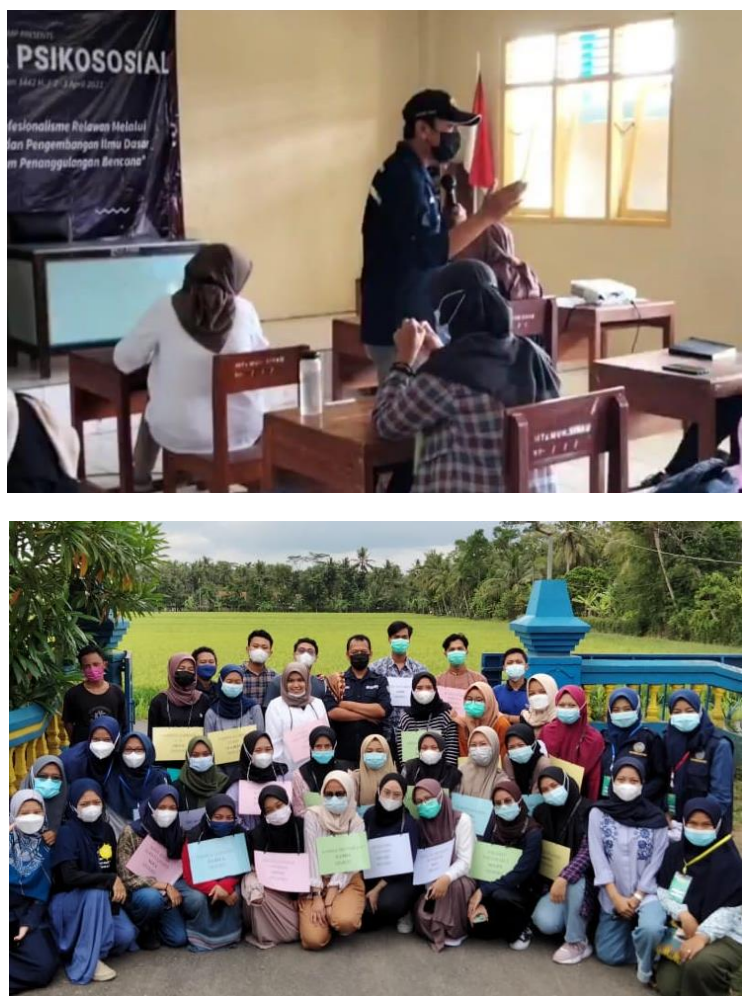

Gambar 4. Dokumentasi kegiatan Pelatihan

Altruisme dalam Kerelawanan

Susunan acara dan tahapan Pelatihan Altruisme dalam Kerelawanan pada Mahasiswa Komunitas Psikososial terdiri dari: (1) mengenal konsep kerelawanan dan kebencanaan; (2) konsep dasar dan pemahaman altruisme yang terdiri dari empati, sikap sukarela, dan perilaku menolong; (3) pengembangan dasar altruisme dalam kerelawanan; dan (4) implementasi altruisme sesuai dengan aktivitas dan kapasitas dalam rangka untuk menguatkan keterampilan sebagai relawan kebencanaan.

1. Evaluasi dan dampak pelatihan altruisme dalam kerelawanan pada Mahasiswa Komunitas Psikososial secara personal.

Para relawan bencana memiliki pemahaman akan kerelawanan, pemahaman sikap altruisme dan pentingnya dalam kerelawanan, mengimplementasikan sikap altruisme dalam organisasi komunitas psikososial, dan optimalisasi altruisme untuk bekerja dalam aktivitas kerelawanan bencana.

Pre dan post-test terdiri dari 10 pertanyaan terkait dengan:

a. Definisi kerelawanan

b. Definisi kebencanaan

c. Jenis-jenis bencana

d. Definisi altruisme

e. Tokoh dalam teori altruisme

f. Konsep altruisme dalam kerelawanan

g. Aspek-aspek altruisme

h. Faktor munculnya altruisme

i. Altruisme dalam kasus bencana alam

j. Altruisme dalam extra-role behavior

Sumber teori: Setiawan \& Sugiarti (2007), Khairil (2014), Moscovici (2015, dan Permatahati (2016).

Hasil dari pre dan post-test yaitu:

a. Dari hasil pretest didapatkan skor rata-rata 7,33 dari total nilai 10.

b. Dari hasil post-test didapatkan skor rata-rata 9,33 dari total nilai 10.

Berdasarkan wawancara sampel, serta observasi atas keantusiasan peserta dalam pelatihan, para peserta merasa puas terhadap metode pelatihan yang disampaikan dengan ceramah interaktif, diskusi, dan simulasi.

2. Evaluasi dan dampak pelatihan terhadap organisasi

Para relawan memiliki pemahaman yang mendalam terhadap altruisme dan sikap-sikap lain atas potensi dirinya sebagai relawan yang kemudian secara luas bisa diintegrasikan dengan kegiatan dan program kerja organisasinya. Dengan altruisme yang dimiliki para anggota organisasi, Khairil (2014) menyatakan bisa mengarahkan diri para relawan untuk berkontribusi dalam organisasi secara 
efektif dan menyadari apa pilihan dan konsekuensi atas aktivitas dalam organisasinya, baik dalam keseharian maupun di lokasi bencana.

Sikap altruisme yang dimiliki para relawan Mahasiswa Komunitas Psikososial, diharapkan akan meningkatkan gairah dan sikap menolong dalam kerelawanan sebagai implementasi altruisme yang telah disadarinya dan bersedia mengikuti follow up yaitu berupa pendampingan keterampilan personal kerelawanan dan pelatihan organisasional lainnya.

\section{KESIMPULAN}

Kesimpulan dari kegiatan pengabdian masyarakat ini yaitu bahwa Pelatihan Altruisme dalam Kerelawanan pada Mahasiswa Komunitas Psikososial sangat tepat diterapkan sebagai salah satu upaya membentuk relawan yang baru bergabung di komunitas psikosial untuk memiliki sikap altruisme. Metode ceramah interaktif, diskusi, dan simulasi menjadi metode yang tepat untuk memberi pemahaman dan implementasi sikap altruisme dalam kerelawanan. Sebagai luaran dalam pelatihan ini yaitu modul pelatihan dan artikel ilmiah, disertai dengan tindak lanjut pengabdian masyarakat ini yaitu pendampingan pasca pelatihan di sekretariat maupun di lapangan/lokasi bencana dan simulasi dalam peningkatan sikap-sikap kerelawanan pada relawan mahasiswa komunitas psikososial.

\section{UCAPAN TERIMA KASIH}

Ucapan terimakasih ditujukan kepada para pihak yang telah membantu terselenggaranya kegiatan ini, baik pihak mahasiswa komunitas psikososial maupun Pondok Pesantren Islam Terpadu Al-Ittihad Kebarongan Kemranjen yang bersedia menjadi tuan rumah dan lokasi pengabdian masyarakat. Terimakasih juga diucapkan pada para mahasiswa relawan psikososial yang bersedia berbagi pengalaman selama kegiatan.

\section{DAFTAR PUSTAKA}

Kamilah, C., \& Erlyani, N. (2017). Gambaran Altruisme Anggota Komunitas 1000 Guru Kalimantan Selatan. Jurnal Ecopsy, 4(1), 33-40.

Karmakar, R., dan Ghosh, A. (2012). Altruistic Behavior of Adolescents of Different Regions of India. Journal of The Indian Academy of Applied Psychology. 38 (44-53)

Khairil. (2014). Analisis Faktorial, Dimensi Altruisme Pada Relawan Bencana Alam. Thesis. Malang: Universitas Islam Negeri Maulana Malik Ibrahim Malang.

Moscovici, S. (2015). " Les formes élémentaires de 1 ' altruisme .," (June).

Permatahati, I. S. (2016). Pengaruh Altruistic Behavior Terhadap Psychological Well Being Pada Relawan di Sanggar Hati Kita Tulungagung. In Psychology \& Humanity (pp. 585-591)

Setiawan, M. B., \& Sugiarti, L. R. (2007). Altruisme Ditinjau Dari Empati Pada Siswa SMK, 39-49

(https://bnpb.go.id/berita/peran-milenialdalam-penanggulangan-bencana. Diterbitkan pada hari Kamis, 16 Januari 2020, pukul. 05:21 WIB). 